UDC 634.4

LBC 4.40 .3

\title{
FEATURES OF THE SOIL COVER OF THE SEMI-DESERT ECOTONE IN THE SOUTH OF THE VOLGA UPLAND
}

\author{
Gleb A. Rulev
}

Federal Research Center for Agroecology, Integrated Land Reclamation and Protective Afforestation of the Russian Academy of Sciences, Volgograd, Russian Federation

\author{
Alexander S. Rulev \\ Federal Research Center for Agroecology, Integrated Land Reclamation and Protective Afforestation \\ of the Russian Academy of Sciences, Volgograd, Russian Federation
}

\begin{abstract}
The semi-desert ecotone of the south of the Volga Upland is part of the zonal macroecotone bordering the Eastern European steppes from the southeast. Under strained hydrothermal conditions, the microrelief plays a decisive role in the redistribution of atmospheric moisture. This article contains materials from 10-year studies of the soil and landscape cover of the contact zone of the south of the Volga Upland and the northern end of Ergeni. The so-called three-membered complex described 100 years ago by N.A. Dimo and B.A. Keller is not traced in the soil cover. The methodology of landscape-catenary sections was used by laying soil-geomorphological profiles and drilling wells with subsequent sampling of soils at 5 test sites. The soil cover of the watersheds of the sites is represented by complexes of light chestnut low-humic weakly alkalinized medium- and heavy-loam soils. A smaller area is occupied by meadow-chestnut soils of cavities and solonets. The structure of the soil cover of the slopes includes combinations and variations that transform into mesocatenes. In the mesocatene of balkas, zonal light chestnut turn into metamorphosed meadow-chestnut soils or drift dark-colored soils of the bottom of balkas. The semi-desert ecotone is almost completely located within the boundaries of the spread of light chestnut soils in Volgograd region. The structure of the soil cover of the ecotone is dominated by a twofold complex, where zonal light chestnut soils in combination with meadow-chestnut soils of cavities and solonets.

Key words: ecotone, catena, soil cover, mesorelief, granulometric composition, microrelief, cavity, padina.

Citation. Rulev G.A., Rulev A.S. Features of the Soil Cover of the Semi-Desert Ecotone in the South of the Volga Upland. Prirodnye sistemy i resursy [Natural Systems and Resources], 2021, vol. 11, no. 1, pp. 42-49. DOI: https://doi.org/10.15688/nsr.jvolsu.2021.1.6
\end{abstract}

УДК 634.4

ББК 4.40 .3

\section{ОСОБЕННОСТИ ПОЧВЕННОГО ПОКРОВА ПОЛУПУСТЫННОГО ЭКОТОНА ЮГА ПРИВОЛЖСКОЙ ВОЗВЫШЕННОСТИ}

\section{Глеб Александрович Рулев}

Федеральный научный центр агроэкологии, комплексных мелиораций и защитного лесоразведения РАН, г. Волгоград, Российская Федерация

\section{Александр Сергеевич Рулев}

Федеральный научный центр агроэкологии, комплексных мелиораций и защитного лесоразведения РАН, г. Волгоград, Российская Федерация

Аннотация. Полупустынный экотон юга Приволжской возвышенности входит в зональный макроэкотон, окаймляющий с юго-востока восточноевропейские степи. В условиях напряженного гидротермическо-
} 
го режима микрорельеф играет определяющую роль в перераспределении атмосферной влаги. В данной статье приведены материалы 10-летних исследований почвенно-ландшафтного покрова зоны контакта юга Приволжской возвышенности и Северного окончания Ергеней. В почвенном покрове не прослеживается так называемый трехчленный комплекс, описанный еще 100 лет назад Н.А. Димо и Б.А. Келлером. Использовалась методология ландшафтно-катенарных сечений путем закладки почвенно-геоморфологических профилей и бурением скважин с последующим отбором образцов почв на 5 тестовых полигонах. Почвенный покров водоразделов полигонов представлен комплексами светло-каштановых малогумусных слабосолонцеватых средне- и тяжелосуглинистых почв. Меньшую площадь занимают лугово-каштановые почвы западин и солонцы. Структура почвенного покрова склонов включает сочетания и вариации, которые трансформируются в мезокатены. В мезокатене балок зональные светло-каштановые переходят в метаморфизированные лугово-каштановые почвы или намытые темноцветные почвы днищ балок. Полупустынный экотон практически полностью расположен в границах распространения светло-каштановых почв на территории Волгоградской области. В структуре почвенного покрова экотона преобладает двучленный комплекс, где зональные светло-каштановые почвы в сочетании с лугово-каштановыми почвами западин и солонцы.

Ключевые слова: экотон, катена, почвенный покров, мезорельеф, гранулометрический состав, микрорельеф, западина, падина.

Цитирование. Рулев Г. А., Рулев А. С. Особенности почвенного покрова полупустынного экотона юга Приволжской возвышенности // Природные системы и ресурсы. - 2021. - Т. 11, № 1. - С. 42-49. - DOI: https://doi.org/10.15688/nsr.jvolsu.2021.1.6

\section{Введение}

Полупустынный экотон юга Приволжской возвышенности практически полностью находится в границах распространения светло-каштановых почв. Этот экотон входит в зональный макроэкотон, окаймляющий с юго-востока восточноевропейские степи $[9 ; 10]$.

В условиях напряженного гидротермического режима полупустыни микрорельеф играет определяющую роль в перераспределении атмосферной и почвенно-грунтовой влаги. Как следствие, на плоскозападинной равнине сформировалась дробная и достаточно контрастная фациальная структура - так называемый трехчленный комплекс, описанный еще 100 лет назад Н.А. Димо и Б.А. Келлером [4]. Каждый из его членов размещается на определенных формах и элементах микрорельефа. При этом образуются микрокатены, включающие несколько высотных ярусов. Сверху вниз по катене друг друга сменяют: а) галофитно-пустынные фации микроповышений; б) пустынно-степные фации межзападинных ложбинообразных понижений и микросклонов к западинам; в) степные и луговостепные фации микрозападин [9].

В полого-волнистом мезорельефе полупустынного экотона юга Приволжской возвышенности не прослеживается четкая картина трехчленного комплекса почвенно-ландшаф- тного покрова. Однако лугово-каштановые (гидрометаморфизированные) почвы западин играют важнейшую роль в структуре почвенного покрова.

Несмотря на крайне малый размах высот, в микрокатене четко проявляется высотная и латеральная поляризация. На одном ее полюсе - в микрозападине - развиваются степные фации. На другом - на межзападинном микроповышении - фации пустынные. Промежуточную позицию занимают «зажатые» между крайними членами комплекса типично зональные для полупустыни фации. На их долю приходится роль катенарного микроэкатона. В описанном трехчлене нетрудно увидеть своеобразное преломление известного «правила предварения» В.В. Алехина [1].

В данной статье приведены материалы 10-летних исследований (2010-2020 гг.) почвенно-ландшафтного покрова зоны контакта юга Приволжской возвышенности и Северных Ергеней.

Цель исследований - выявить особенности почвенного покрова полупустынного экотона юга Приволжской возвышенности. В задачи исследований входило изучение структур почвенного покрова различного уровня сложности путем закладки почвенно-геоморфологических профилей и бурением скважин с последующим отбором образцов почв на тестовых полигонах. 


\section{РЕСУ РСОВЕДЕНИЕ}

\section{Материалы и методы исследования}

Использовалась методология ландшафтно-катенарных сечений, включающая изучение: мезорельефа, пластики рельефа (соотношение положительных и отрицательных элементов мезорельефа), микрорельеф и структуру почвенного покрова.

Эта методология основывается на сравнительно-географическом подходе В.И. Фридланда $[5 ; 16]$. Он включает описание таксономических признаков почв (полевое название), мезорельефа (плакоры, низины, мезосклоны), условия увлажнения (автоморфные, гидроморфные, полугидроморфные), литологический состав пород, гранулометрический состав, карбонатность (глубина вскипания), мощность гумусового горизонта $\left(\mathrm{A}+\mathrm{AB}_{1}, \mathrm{~cm}\right)$.

Выделяются шесть групп почвенных комбинаций:

1. Комплексы - обусловлены микрорельефом, почвы контрастно различаются.

2. Пятнистости - то же что комплексы, но почвы слабоконтрастны.

3. Сочетания - обусловлены мезорельефом, вышезалегающие почвы воздействуют на нижезалегающие.

4. Вариации - то же что сочетания, но почвы слабоконтрастны.

5. Мозаики - обусловлены различиями в почвообразующих породах, представлены резко контрастными почвами.

6. Ташеты - представлены слабоконтрастными почвами, формируются под воздействием биологических факторов, например, смены растительности.

Основной объект исследований мезокатены [13], которые состоят из почвенных комбинаций, которые по степени сложности делятся на 2 уровня. Простые почвенные комбинации образованы элементарными почвенными ареалами, например, комплексы солонцов и каштановых почв. Сложные почвенные комбинации, компонентами которых являются простые почвенные, представляют собой второй уровень сложных единиц почвенного покрова или третий уровень таксономических единиц почвенного покрова. К числу сложных комбинаций относятся только сочетания, вариации, мозаики и ташеты.
Исследования проводились на полигонах «Дубовка», «Городище», «Лысая гора», относящихся к полупустынному экотону юга Приволжской возвышенности, а также на полигонах «Чапурниковская балка», «Тингута» Северные Ергени.

\section{Результаты и обсуждение}

В «Классификации почв России» 2004 г. $[11 ; 17]$ систематика почв каштанового типа претерпела существенные изменения. Подтипы каштановых и светло-каштановых почв выделяются на уровне типа в отделе аккумулятивно-карбонатных малогумусовых почв под названием «каштановые почвы». Некоторая часть светло-каштановых почв отнесена к типу бурых почв этого же отдела. Неполноразвитый род помещен вместе с неполноразвитыми бурыми полупустынными почвами в отдел органо-аккумулятивных почв под названием светло-гумусовые почвы. Темно-каштановые почвы отнесены к другому отделу. Они совместно с черноземами южными образуют тип черноземов текстурно-карбонатных в отделе аккумулятивно-гумусовых почв.

Разделение типа на подтипы в классификации 2004 года осуществлено по признакам солонцеватости, засоления и гидроморфизма, а также в связи с агрогенными нарушениями верхней части профиля. Выделено 5 подтипов: типичные, солонцеватые, засоленные, гидрометаморфозные (по классификации 1977 г. [6] - это луговато-каштановые почвы) и турбированные.

Согласно данным по гранулометрическому составу полигона «Дубовка» (см. табл. 1), характеризуемые почвы суглинистые и тяжелосуглинистые с доминирующими фракциями в порядке убывания их доли: мелкого песка $(0,05-0,25$ мм), ила $(<0,001$ мм) и крупной пыли $(0,01-0,05$ мм). Самую большую долю составляет фракция мелкого песка - от 23 до $49 \%$, преимущественно 30-40 \%. Содержание илистой фракции изменяется в пределах 20-28 \%. На долю крупной пыли приходится от 12 до $32 \%$, чаще $15-25 \%$.

Количество гумуса в поверхностном горизонте варьирует от 0,87 до $0,52 \%$, в горизонте $\mathrm{AB}-0,77-0,43 \%$, в материнской поро- 
де C (80-120 см) - 0,21-0,17 \%. Наибольшее содержание углерода приурочено к горизонту А (0-20 см) - 0,49-0,29\%. Вниз по почвенному профилю содержание углерода падает. Отмечается облегчение гранулометрического состава до суглинка среднего. Содержание гумуса представлено в таблице 2.

На полигоне «Дубовка» почвенный покров водоразделов представлен комплексами светло-каштановых и каштановых малогумусных слабосолонцеватых средне- и тяжелосуглинистых почв. Меньшую площадь занимают лугово-каштановые почвы и солонцы. По лесорастительным свойствам выделяется следующий ряд: лугово-каштановые (лучшие), каштановые и свело-каштановые почвы, сильносолонцеватые почвы и солонцы (худшие) [8; 12].
Лугово-каштановые почвы, залегающие в слабых микропонижениях (западинах), обладают наиболее благоприятным водным режимом.

Почвы западин развиваются под влиянием дополнительного увлажнения за счет поверхностного стока и мощной травянистой растительности. Это усиливает дерновый процесс почвообразования, степень выраженности которого зависит от глубины западины. Чем больше глубина западины, тем больший слой воды в ней накапливается, глубже промачивается и выщелачивается почва, лучше развивается растительность, больше образуется гумуса при ее разложении. Почвы западин можно разделить на лугово-каштановые в мелких, глубиной до 20 см западинах, гумусовый горизонт A+B $40-60$ см и

\section{Гранулометрический состав светло-каштановой почвы (полигон «Дубовка»)}

Таблий 1

\begin{tabular}{|c|c|c|c|c|c|c|c|c|c|c|}
\hline \multirow{2}{*}{$\begin{array}{l}\text { Ключе- } \\
\text { вой } \\
\text { участок }\end{array}$} & \multirow[b]{2}{*}{ Глубина } & \multirow{2}{*}{$\begin{array}{c}\text { Гигр. } \\
\text { влаж- } \\
\text { ность, \% }\end{array}$} & \multicolumn{7}{|c|}{ Размер фракции, мм } & \multirow[b]{2}{*}{$\begin{array}{c}\text { Название почв } \\
\text { по ГМС }\end{array}$} \\
\hline & & & $1-0,25$ & $\begin{array}{c}0,25- \\
0,05\end{array}$ & $\begin{array}{c}0,05- \\
0,01\end{array}$ & $\begin{array}{l}0,01- \\
0,005\end{array}$ & $\begin{array}{c}0,005- \\
0,001\end{array}$ & $<0,001$ & $\begin{array}{c}\text { Физ. } \\
\text { глина }\end{array}$ & \\
\hline \multirow{7}{*}{1} & $0-20$ & 13,6 & 7,8 & 30,7 & 12,0 & 6,4 & 17,0 & 26,1 & 38,5 & Суглинок средний \\
\hline & $20-40$ & 4,16 & 7,7 & 32,2 & 5,5 & 6,3 & 19,1 & 29,2 & 30,9 & Суглинок средний \\
\hline & $40-60$ & 3,0 & 9,0 & 49,6 & 5,6 & 6,5 & 20,1 & 9,2 & 32,2 & Суглинок средний \\
\hline & $60-80$ & 3,1 & 3,2 & 38,9 & 14,0 & 7,8 & 23,6 & 12,5 & 40,0 & Суглинок средний \\
\hline & $80-100$ & 4,2 & 6,6 & 39,3 & 7,25 & 7,1 & 18,4 & 21,35 & 32,75 & Суглинок средний \\
\hline & $100-120$ & 3,1 & 3,65 & 46,0 & 9,0 & 6,1 & 25,9 & 41,35 & 40,9 & Суглинок средний \\
\hline & $120-140$ & 4,2 & 2,4 & 37,7 & 16,6 & 7,8 & 24,3 & 11,2 & 48,7 & Суглинок тяжелый \\
\hline \multirow{7}{*}{2} & $0-20$ & 4,2 & 0,51 & 44,9 & 0,91 & 15,5 & 32,2 & 7,5 & 47,6 & Суглинок тяжелый \\
\hline & $20-40$ & 5,3 & 0,41 & 1,39 & 12,6 & 12,1 & 28,3 & 44,7 & 53,0 & Суглинок тяжелый \\
\hline & $40-60$ & 4,2 & 0,38 & 39,9 & 9,3 & 13,0 & 27,6 & 9,7 & 49,9 & Суглинок тяжелый \\
\hline & $60-80$ & 4,2 & 0,33 & 41,9 & 8,2 & 13,0 & 27,3 & 9,5 & 48,5 & Суглинок тяжелый \\
\hline & $80-100$ & 4,2 & 1,27 & 43,3 & 6,0 & 11,6 & 25,05 & 12,7 & 42,6 & Суглинок средний \\
\hline & $100-120$ & 3,1 & 0,63 & 44,7 & 8,1 & 11,8 & 27,9 & 6,9 & 47,8 & Суглинок тяжелый \\
\hline & $120-140$ & 4,2 & 0,63 & 21,2 & 22,2 & 9,3 & 31,8 & 14,9 & 63,3 & Глина легкая \\
\hline
\end{tabular}

Таблийа 2

\section{Содержание углерода и гумуса в светло-каштановой почве (полигон «Дубовка»)}

\begin{tabular}{|c|c|c|c|}
\hline Ключевой участок & Глубина & Содержание углерода, \% & Содержание гумуса, \% \\
\hline \multirow{4}{*}{1} & $0-20$ & 0,49 & 0,87 \\
\cline { 2 - 4 } & $20-40$ & 0,43 & 0,77 \\
\cline { 2 - 4 } & $40-60$ & 0,53 & 0,94 \\
\cline { 2 - 4 } & $60-80$ & 0,46 & 0,81 \\
\cline { 2 - 4 } & $80-100$ & 0,12 & 0,21 \\
\hline \multirow{5}{*}{2} & $100-120$ & 0,12 & 0,21 \\
\cline { 2 - 4 } & $0-20$ & 0,29 & 0,52 \\
\cline { 2 - 4 } & $20-40$ & 0,24 & 0,43 \\
\cline { 2 - 4 } & $40-60$ & 0,05 & 0,09 \\
\cline { 2 - 4 } & $60-80$ & 0,07 & 0,13 \\
\cline { 2 - 4 } & $80-100$ & 0,09 & 0,17 \\
\hline
\end{tabular}


мощные темноцветные почвы (черноземовидные) глубоких бессточных западин и балок, где толщина гумусового горизонта достигает 70-100 см [2; 3].

С целью получения дополнительной информации о пространственном распределении отрицательных форм мезо- и микрорельефа (падин и западин), как наиболее ценных экотопов для лесомелиорации, был проведен анализ их морфометрических показателей. Западины представляют собой замкнутые понижения с плоским и слабо вогнутым дном диаметром от 1 до 20-30 м и глубиной 5-50 cм, имеют круглую, овальную, грушевидную форму или неправильные сочетания. Падины представляют собой замкнутые неглубокие $(1,0-1,5$ м) понижения.

Статистическая обработка данных по встречаемости западин с различной площадью позволила установить, что распределение площадей западин и падин имеет логарифмически нормальный характер [13].

На основании проведенных исследований предлагается следующая классификация западин и падин в зависимости от их площади: западины мелкие $(<0,01$ га), средние $(0,01-$ 0,05 га), крупные $(0,05-0,25$ га); падины мелкие $(0,25-2,5$ га), средние $(2,5-5,0$ га), крупные (5,0-50 га), сверхкрупные (>50 га).

Структура почвенного покрова полигонов «Городище» и «Лысая гора» принципиально не отличается от почвенного покрова полигона «Дубовка» и ранее их описание в совместных работах опубликовано [14; 15]

Полупустынный экотон южного окончания Приволжской возвышенности в районе балки Отрада переходит в северное окончание Ергенинской возвышенности.

Чапурниковская балка имеет протяженность 4 км, она простирается с севера на югозапад, имея в плане дугообразную форму и многочисленные отвершки. Густота эрозионного расчленения достигает 1,5 км на км². Характер расчленения почти симметричный. Глубина основного вреза достигает 30-35 м в средней части, уменьшаясь в низовье до 10 м. Абсолютные высоты $+120,+140$ метров. Плато сложено с поверхности мощной, свыше 30 м толщей неогеновых (ергенинских) белых песков, мелко- и среднезернистых, переполненных стяжениями рыхлых песчаников, так называемых «фигурных». Горизонт ергенинских песков местами покрыт суглинками желто-бурого цвета.

В таблице 3 дана характеристика гранулометрического состава почв балки. B.М. Кретинин [7] выделяет в мезокатене Чапурниковской балки следующие типы почв.

Зональные светло-каштановые почвы водоразделов и склонов характеризуются маломощностью, укороченностью почвенного профиля, малогумусностью, легким грану-

Таблича 3

\section{Характеристика светло-каштановых почв по гранулометрическому составу} (тестовый полигон «Чапурники»)

\begin{tabular}{|c|c|c|c|c|c|c|c|c|c|c|}
\hline \multirow[b]{2}{*}{ Типы почвы } & \multirow{2}{*}{$\begin{array}{c}\text { Горизонт, } \\
\text { глубина, } \\
\text { см }\end{array}$} & \multirow{2}{*}{$\begin{array}{c}\text { Гумус, \% } \\
\text { (по Тюри- } \\
\text { ну) }\end{array}$} & \multicolumn{8}{|c|}{ Гранулометрический состав, \%; размер части, мм } \\
\hline & & & $>1$ & $1-0,25$ & $\begin{array}{c}0,25- \\
0,05\end{array}$ & $\begin{array}{c}0,05- \\
0,01\end{array}$ & $\begin{array}{l}0,01- \\
0,005\end{array}$ & $\begin{array}{r}0,005- \\
0,001\end{array}$ & $<0,001$ & $\begin{array}{c}\text { Сумма час- } \\
\text { тиц }<0,01\end{array}$ \\
\hline \multirow{5}{*}{$\begin{array}{l}\text { Светло- } \\
\text { каштановая } \\
\text { суглини- } \\
\text { стая }\end{array}$} & $\mathrm{A}_{\Pi} 0-6$ & 2,42 & - & 0,3 & 7,7 & 34,4 & 12,7 & 12,0 & 30,7 & 55,4 \\
\hline & $\mathrm{B}_{1} 18-28$ & 1,51 & - & 0,2 & 6,2 & 34,8 & 6,7 & 11,8 & 37,7 & 56,2 \\
\hline & $\mathrm{B}_{2} 28-38$ & 1,25 & - & - & 4,8 & 36,0 & 6,0 & 9,9 & 36,0 & 54,9 \\
\hline & BC 40-50 & 1,00 & - & 0,2 & 4,6 & 33,7 & 6,3 & 8,5 & 31,1 & 45,9 \\
\hline & C 60-70 & - & - & - & 8,1 & 34,2 & 5,7 & 8,9 & 24,9 & 49,5 \\
\hline \multirow{3}{*}{$\begin{array}{l}\text { Светло- } \\
\text { каштановая } \\
\text { суглини- } \\
\text { стая, силь- } \\
\text { но солон- } \\
\text { цеватая }\end{array}$} & $\mathrm{A}_{1} 0-10$ & 1,56 & 0,7 & 4,5 & 24,2 & 34,0 & 5,2 & 5,6 & 23,8 & 34,6 \\
\hline & $\mathrm{A}_{2} 10-17$ & 1,55 & 0,7 & 4,3 & 23,9 & 35,6 & 4,3 & 6,8 & 23,2 & 34,3 \\
\hline & $\mathrm{B}_{1} 20-30$ & 1,09 & 0,3 & 2,9 & 16,2 & 30,1 & 7,0 & 4,8 & 36,4 & 49,2 \\
\hline \multirow{4}{*}{$\begin{array}{l}\text { Лугово- } \\
\text { каштановая } \\
\text { намытая } \\
\text { суглини- } \\
\text { стая }\end{array}$} & $\mathrm{A}_{\Pi} 0-6$ & 3,27 & - & 0,8 & 8,5 & 34,4 & 6,5 & 11,4 & 33,6 & 51,5 \\
\hline & $A_{1} 10-20$ & 4,21 & - & 1,7 & 7,8 & 37,1 & 6,2 & 10,7 & 34,0 & 51,7 \\
\hline & $\mathrm{B}_{2} 50-60$ & 2,05 & - & 1,0 & 8,5 & 38,7 & 6,2 & 9,4 & 34,4 & 50,0 \\
\hline & $\mathrm{C}_{1} 90-100$ & - & - & 1,1 & 8,9 & 38,4 & 6,0 & нет & нет & нет \\
\hline
\end{tabular}


лометрическим составом, эродированностью и слабой засоленностью.

Второй тип представлен лесо-каштановыми среднегумусными маломощными легкосуглинистыми почвами. Он располагается в верховьях гидрографической балочной сети и на нижнем склоне балки.

Почвы сформировались под нагорными байрачными лесами (преимущественно дубравами порослевого и семенного происхождения). Почвы незасоленные, на поверхности образован слой лесной подстилки. Водный режим почвы относят к промывному и периодически-промывному типам. Характерно дополнительное увлажнение за счет поверхностного стока талых и ливневых вод. Почвы относятся к первой группе лесопригодности.

Следующий тип представлен луговатолесными, гумусовыми маломощными суглинистыми почвами днищ балок на аллювиальных супесях и суглинках. Почвы сформировались под байрачными дубравами с участием злаково-разнотравной растительности. На поверхности почвы слой лесной подстилки. Почвы незасоленные, характерен промывной тип водного режима. Грунтовые воды залегают на глубине 3-5 м. Отмечено захламление почв, хищение верхнего плодородного горизонта.

Четвертый тип представлен аллювиальными темноцветными гумусными среднемощными тяжелосуглинистыми лесными почвами на суглинках. Почвы сформировались под ольшаником, представленным тополем черным. Участие травянистой растительности в почвообразовании ограниченное. Характерно обильное увлажнение за счет поверхностного и внутригрунтового стока, выхода родников. Верховодка залегает на глубине 1-2 м. На поверхности почвы лесная подстилка относительно тонкая из-за ускоренного разложения опада. В нижней части профиля отмечается оглеение, переувлажнение. Почвы незасолены, обладают высокой лесопригодностью.

Все лесные почвы Чапурниковской балки в Красной книге почв Волгоградской области [7] отнесены к категориям эталонов на территории России. Они нуждаются в охране и изучении, классификации.

Почвенный покров полигона «Тингута» представлен среднесуглинистыми, легкосуглинистыми и супесчаными светло-каштановыми почвами. Гранулометрический состав показан в таблице 4. Засоленность таких почв небольшая. Агроземы сельскохозяйственных полей малогумусные, незасоленные. Почвы западин и днищ балок - лугово-каштановые, среднегумусные, среднемощные, легкосуглинистые и суглинистые.

\section{Заключение}

Полупустынный экотон юга Приволжской возвышенности практически полностью

Таблиияа 4

Характеристика светло-каштановых почв (тестовый полигон «Тингута»)

\begin{tabular}{|c|c|c|c|c|c|c|c|c|c|c|}
\hline \multirow[b]{2}{*}{ Типы почвы } & \multirow[b]{2}{*}{$\begin{array}{c}\text { Горизонт, } \\
\text { глубина, } \\
\text { см }\end{array}$} & \multirow[b]{2}{*}{$\begin{array}{c}\text { Гумус, } \\
\text { \% (по } \\
\text { Тюрину) }\end{array}$} & \multicolumn{8}{|c|}{ Гранулометрический состав, \%; размер части, мм } \\
\hline & & & $>1$ & $\begin{array}{c}1- \\
0,25\end{array}$ & $\begin{array}{c}0,25- \\
0,05\end{array}$ & $\begin{array}{c}0,05- \\
0,01\end{array}$ & $\begin{array}{l}0,01- \\
0,005\end{array}$ & $\begin{array}{c}0,005- \\
0,001\end{array}$ & $<0,001$ & $\begin{array}{c}\text { Сумма } \\
\text { частиц } \\
<0,01\end{array}$ \\
\hline \multirow{4}{*}{$\begin{array}{l}\text { Светло- } \\
\text { каштановая сред- } \\
\text { несуглинистая }\end{array}$} & $\mathrm{A}_{1} 5-15$ & 1,41 & 0,5 & 7,4 & 32,9 & 22,0 & 7,5 & - & 22,7 & 30,2 \\
\hline & $\mathrm{B}_{2} 15-25$ & 1,00 & 0,4 & 6,4 & 22,8 & 25,3 & 4,7 & 3,8 & 25,1 & 33,6 \\
\hline & $\mathrm{C}_{1} 30-40$ & 0,59 & 0,5 & 6,5 & 24,2 & 22,9 & 6,1 & 1,0 & 22,7 & 29,8 \\
\hline & $\mathrm{C}_{2} 40-50$ & 0,46 & 0,5 & 6,9 & 22,2 & 25,4 & 4,7 & 3,2 & 20,3 & 28,2 \\
\hline \multirow{4}{*}{$\begin{array}{l}\text { Светло- } \\
\text { каштановая легко- } \\
\text { суглинистая }\end{array}$} & $\mathrm{A}_{1} 15-25$ & 1,85 & 0,3 & 5,9 & 25,7 & 28,6 & 4,2 & 4,4 & 22,7 & 31,3 \\
\hline & $\mathrm{B}_{1} 30-40$ & 1,63 & 0,2 & 5,5 & 24,4 & 26,6 & 5,4 & 4,9 & 22,3 & 32,6 \\
\hline & $\mathrm{B}_{2} 48-56$ & 1,24 & 0,3 & 9,9 & 24,4 & 23,9 & 1,8 & 5,3 & 19,8 & 26,9 \\
\hline & $\mathrm{C}_{1} 70-80$ & - & 0,2 & 3,8 & 10,7 & 36,1 & 5,4 & 4,1 & 24,7 & 34,2 \\
\hline \multirow{5}{*}{$\begin{array}{l}\text { Лугово- } \\
\text { каштановая сред- } \\
\text { несуглинистая }\end{array}$} & $\mathrm{A}_{1} 8-20$ & 3,15 & - & 4,6 & 36,4 & 34,7 & 7,6 & 12,2 & 3,9 & 25,1 \\
\hline & $\mathrm{B}_{1} 20-30$ & 1,49 & - & 4,0 & 40,0 & 24,7 & 10,3 & 14,5 & 5,1 & 31,3 \\
\hline & $\mathrm{B}_{2} 40-55$ & 1,93 & - & 3,2 & 52,2 & 14,7 & 8,7 & 13,7 & 6,5 & 31,4 \\
\hline & $\mathrm{C}_{1} 90-100$ & - & - & 9,4 & 37,4 & 22,4 & 5,5 & 11,2 & 4,7 & 22,9 \\
\hline & $\begin{array}{c}\mathrm{C}_{2} 190- \\
200\end{array}$ & - & - & 7,4 & 46,0 & 22,4 & 6,8 & 8,6 & 3,9 & 20,8 \\
\hline
\end{tabular}


расположен в границах распространения светло-каштановых почв на территории Волгоградской области. В структуре почвенного покрова экотона преобладает двучленный комплекс, где лугово-каштановые почвы западин играют важнейшую роль.

\section{СПИСОК ЛИТЕРАТУРЫ}

1. Алехин, В. В. Теоретические проблемы фитоценологии и степеведения / В. В. Алехин. - М. : Изд-во МГУ, 1986. - 211 с.

2. Вадюнина, А. Ф. Агрофизическая и мелиоративная характеристика почв юго-востока европейской части СССР / А. Ф. Вадюнина. - М. : Изд-во МГУ, 1970.-325 c.

3. Васильков, В. Ф. Почвы Юга России / В. Ф. Вальков, К. Ш. Казеев, С. И. Колесников. Ростов н/Д : Эверест, 2008. -276 с.

4. Дино, Н. А. В области полупустыни. Почвенные и ботанические исследования на юге Царицынского уезда Саратовской губернии / Н. А. Дино, Б. А. Келлер. - Саратов : Изд-во Сарат. Губерн. Земства. Почв. лаб., $1907 .-578 \mathrm{c}$.

5. Евдокимова, Т.И. Почвенная съемка/ Т. И. Евдокимова. -М. : Изд-во МГУ, 1981. -264 с.

6. Иванова, Е. Н. Классификация и диагностика почв СССР / Е. Н. Евдокимова. - М. : Наука, 1976. $-226 \mathrm{c}$.

7. Красная книга почв Волгоградской области / К. Н. Кулик, В. М. Кретинин, А. С. Рулев, В. М. Шишкунов. - М. : Изд-во «Волгоград», 2017. - 224 с.

8. Кретинин, В. М. Агролесомелиорация почв / В. М. Кретинин. - Волгоград : ВНИАЛМИ, 2009. $-198 \mathrm{c}$.

9. Николаев, В. А. Евразийская полупустыня (к 100-летию открытия полупустынной природной зоны) / В. А. Николаев // Вестник Московского университета. Серия 5, География. - 2007. № 6. - C. 3-9.

10. Николаев, В. А. Ландшафтный экотон в прикаспийской полупустыне / А.В. Николаев, И.В. Копыл, Г.В. Линдеман // Вестник Московского университета. Серия 5, География. - 1997. - № 2.C. 34-39.

11. Полевой определитель почв России. - М. : Почв. ин-т В.В. Докучаева, 2008. - 182 с.

12. Полезащитное лесоразведение на каштановых почвах. - М. : Изд-во МГУ, 1971. - Вып. 2. -238 с.

13. Рулев, А. С. Ландшафтно-географический подход в агролесомелиорации / А. С. Рулев. - Волгоград : ВНИАЛМИ, 2007. -160 c.

14. Рулев, А. С. Характеристика каштановых почв придорожных лесомелиоративных комплексов
/ А. С. Рулев, Г. А. Рулев // Известия Нижневолжского агроуниверситетского комплекса: наука и высшее образование. - 2018. - Т. 2, № 50 - С. 91-100.

15. Рулев Г.А. Почвенно-геоморфологический анализ придорожных лесомелиорируемых комплексов / Г. А. Рулев, А. С. Рулев, В. Г. Юферев // Известия Нижневолжского агроуниверситетского комплекса: наука и высшее образование. -2018 . T. 1, № 49. - C. 123-131. - DOI: https://doi.org/ 10.32786/2071-9485-2018-02-123-131.

16. Фридланд, В. М. Структура почвенного покрова / В. М. Фридланд. - М. : Мысль, 1972. - 416 с.

17. Шишов, Л. Л. Классификация и диагностика почв России / Л. Л. Шишов, И. И. Лебедева, М. И. Герасимова. - Смоленск : Ойкумена, 2004. $342 \mathrm{c}$.

\section{REFERENCES}

1. Alyokhin V.V. Teoreticheskie problemy fitotsenologii i stepevedeniia [Theoretical Problems of Phytocenology and Steppe studies]. Moscow, Izd-vo MGU, $1986.211 \mathrm{p}$.

2. Vadyunina A.F. Agrofizicheskaia $i$ meliorativnaia kharakteristika pochv iugo-vostoka evropeiskoi chasti SSSR [Agrophysical and Meliorative Characteristics of Soils of The South-East OfThe European Part OfThe USSR]. Moscow, Izd-vo MGU, 1970, 325 p.

3. Vasilkov V.F., Kazeev K.Sh., Kolesnikov S.I. Pochvy Inga Rossii [Soils of the South of Russia]. Rostov-on-Don, Everest Publ., 2008. 276 p.

4. Dino N.A., Keller B.A. Voblasti polupustyni. Pochvennye i botanicheskie issledovaniia na iuge Tsaritsynskogo uezda Saratovskoi gubernii [In the Semidesert Region. Soil and Botanical Studies in the South of the Tsaritsyn District of the Saratov Province]. Saratov, Izd-vo Saratovskogo Gubernskogo Zemstva. Pochvennaia laboratoriia, $1907.576 \mathrm{p}$.

5. Evdokimova T.I. Pochvennaia sieemka [Soil Survey]. Moscow, Izd-vo MGU, 1981. 264 p.

6. Ivanova E.N. Klassifikatsiya i diagnostika pochv SSSR [Classification and Diagnostics of Soils of the USSR]. Moscow, Nauka Publ., 1976. 226 p.

7. Kulik K.N., Kretinin V.M., Rulev A.S., Shishkunov V.M. Krasnaia kniga pochv Volgogradskoi oblasti [Red Book of Soils of the Volgograd Region]. Moscow, Volgograd Publ., 2017. 224 p.

8. Kretinin V.M. Agrolesomelioratsiia pochv [Agroforestry of Soils]. Volgograd, VNIALMI, 2009. $198 \mathrm{p}$.

9. Nikolaev V.A. Evraziiskaia polupustynia (k 100letiiu otkrytiia polupustynnoi prirodnoi zony) [Eurasian semi-desert (to the $100^{\text {th }}$ anniversary of the discovery of the semi-desert natural zone)]. Vestnik Moskovskogo 
universiteta. Seriia 5, Geografiia [Bulletin of the Moscow University. Series 5. Geography], 2007, no. 6, pp. 3-9.

10. Nikolaev V.A., Kopyl I.V., Lindeman G.V. Landshaftnyi ekoton $\mathrm{v}$ prikaspiiskoi polupustyne [Landscape ecotone in the Caspian semi-desert]. Vestnik Moskovskogo universiteta. Seriia 5, Geografiia [Bulletin of the Moscow University. Series 5. Geography], 1997, no. 2, pp. 34-39.

11. Polevoi opredelitel pochv Rossii [Field Determinant of the Soils of Russia]. Moscow, Pochvennyi in-t V.V. Dokuchaeva, 2008. 182 p.

12. Polezashchitnoe lesorazvedenie na kashtanovykh pochvakh [Useful Protective Forest Cultivation On Chestnut Soils]. Moscow, Izd-vo MGU, 1971, iss. 2. 238 p.

13. Rulev A.S. Landshaftno-geograficheskii podkhod $v$ agrolesomelioratsii [Landscapegeographical approach in agroforestry]. Volgograd, VNIALMI, 2007. $160 \mathrm{p}$.

14. Rulev A.S., Rulev G.A. Kharakteristika kashtanovykh pochv pridorozhnykh lesomeliorativnykh kompleksov [Characteristic of chestnut soils of roadside forest-reclamation complexes]. Izvestiia Nizhnevolzhskogo agrouniversitetskogo kompleksa: nauka i vysshee obrazovanie [News nizhnevolzhskaya agrouniversity complex: science and higher education], 2018, vol. 2, no. 50, pp.91-100.

15. Rulev G.A., RulevA.S., Uferev V.G. Pochvennogeomorfologicheskii analiz pridorozhnykh lesomelioriruemykh kompleksov [Pochvennogeomorphologicheskiy analiz pridorozhnykh lesomelioriruemykh kompleksov]. Izvestiia Nizhnevolzhskogo agrouniversitetskogo kompleksa: nauka $i$ vysshee obrazovanie [Bulletin of the Nizhnevolzhsky agro-university complex: science and higher education], 2018, vol. 1, no. 49, pp. 123-131. DOI: https://doi.org/10.32786/2071-9485-2018-02-123-131.

16. Friedland V.M. Struktura pochvennogo pokrova [The structure of the soil cover]. Moscow, Mysl Publ., 1972. 416 p.

17. Shishov L.L., Lebedeva. I.I., Gerasimova M.I. Klassifikatsiia $i$ diagnostika pochv Rossii [Classification and diagnostics of soils of Russia], Smolensk, Oikumena Publ., 2004. 342 p.

\section{Information About the Authors}

Gleb A. Rulev, Candidate of Sciences (Agriculture), Researcher, Laboratory of Prediction of Agro-Forest Landscapes Bioproductivity, Federal Research Center for Agroecology, Integrated Land Reclamation and Protective Afforestation of the Russian Academy of Sciences, Prosp. Universitetsky, 97, 400062 Volgograd, Russian Federation, g.heroes@yandex.ru

Alexander S. Rulev, Doctor of Sciences (Agriculture), Academician of the Russian Academy of Sciences, Chief Researcher, Laboratory of Prediction of Agro-Forest Landscapes Bioproductivity, Federal Research Center for Agroecology, Integrated Land Reclamation and Protective Afforestation of the Russian Academy of Sciences, Prosp. Universitetsky, 97, 400062 Volgograd, Russian Federation, Rulev54@rambler.ru

\section{Информация об авторах}

Глеб Александрович Рулев, кандидат сельскохозяйственных наук, научный сотрудник лаборатории прогнозирования биопродуктивности агролесоландшафтов, Федеральный научный центр агроэкологии, комплексных мелиораций и защитного лесоразведения РАН, просп. Университетский, 97, 400062г. Волгоград, Российская Федерация, g.heroes@yandex.ru

Александр Сергеевич Рулев, доктор сельскохозяйственных наук, академик РАН, главный научный сотрудник лаборатории прогнозирования биопродуктивности агролесоландшафтов, Федеральный научный центр агроэкологии, комплексных мелиораций и защитного лесоразведения РАН, просп. Университетский, 97, 400062 г. Волгоград, Российская Федерация, Rulev54@rambler.ru 